\title{
A Sustainable and Low-Cost Soil Filter Column for Removing Pathogens from Swine Wastewater: The Role of Endogenous Soil Protozoa
}

\author{
Lavane Kim $^{1, *(D)}$, Tao Yan ${ }^{2}$, Russell Yost ${ }^{3}$ and Guy Porter ${ }^{3}$ \\ 1 Department of Environmental Engineering, College of Environment and Natural Resources, Can Tho \\ University, Can Tho City 94115, Vietnam \\ 2 Department of Civil and Environmental Engineering, University of Hawaii at Manoa, \\ Honolulu, HI 96848, USA; taoyan@hawaii.edu \\ 3 Department of Tropical Plant and Soil Science, University of Hawaii at Manoa, Honolulu, HI 96848, USA; \\ rsyost@hawaii.edu (R.Y.); porterg004@hawaii.rr.com (G.P.) \\ * Correspondence: klavane@ctu.edu.vn
}

\section{check for} updates

Citation: Kim, L.; Yan, T.; Yost, R.; Porter, G. A Sustainable and Low-Cost Soil Filter Column for Removing Pathogens from Swine Wastewater: The Role of Endogenous Soil Protozoa. Water 2021, 13, 2472. https://doi.org/10.3390/w13182472

Academic Editors: Didier Orange, Magali Gerino, Jérôme Harmand, Marjorie Le Bars, Nguyen Thai Huyen and Pascal Breil

Received: 20 July 2021

Accepted: 3 September 2021

Published: 8 September 2021

Publisher's Note: MDPI stays neutral with regard to jurisdictional claims in published maps and institutional affiliations.

Copyright: (c) 2021 by the authors. Licensee MDPI, Basel, Switzerland. This article is an open access article distributed under the terms and conditions of the Creative Commons Attribution (CC BY) license (https:/ / creativecommons.org/licenses/by/ $4.0 /)$.

\begin{abstract}
The increase of swine production in the Pacific Islands has inevitably led to environmental pollution concerns from discharged wastewater derived from both washing and manure. The slurry accumulates in lagoons, where supernatant wastewater containing high levels of pathogens and nutrients becomes nonpoint source water pollution that deteriorates the quality of receiving water bodies. Soil filtration is a promising cost-effective technology for removing pollutants from swine wastewater; however, the excessive growth of bacteria in soil media often accompanies the filtration process. This study investigates soil filtration mediated by protozoa activities to remove Escherichia coli (E. coli) in synthetic swine wastewater. The experiment used plastic columns packed with Leilehua soil from Oahu Island, Hawaii. The soil physicochemical adsorption was seen to reduce 95.52-96.47\% of E. coli. However, the average removal efficiencies were increased to $98.17 \%$ in a single stage, and $99.99 \%$ in two sequential columns, under predation conditions. The filtration media containing naturally established bacterivores with the prey, provided a bioactive means to remove E. coli from the influent. The proper design of Leilehua soil filters potentially removes E. coli from the influent to meet the standard level of recycled water.
\end{abstract}

Keywords: bioactive soil; protozoa; E. coli; removal efficiency; swine production effluent

\section{Introduction}

Developing and implementing economic and sustainable swine waste management systems in the Pacific Islands as well as other watershed environments are important to agricultural activities and environmental protection. Swine manure generally contains high levels of organic matter, nutrients, and pathogens, and thus can be considered as a point source of nutrients from agriculture, as well as a source of nonpoint pollution via runoff and seepage to nearby waterbodies. Traditional treatment methods primarily focus on removing solid contents via sedimentation and anaerobic digestion in lagoons for subsequent disposal [1,2]. However, lagoon supernatants contain high levels of biological contaminants [3] and are often used to irrigate crops or discharged into adjacent streams, which indirectly or directly threatens fragile aquatic systems. A major concern is that swine wastewater contains high levels of pathogenic bacteria with high antibiotic resistance [1,4-6]. A review by Guan and Holley (2003) concluded that pathogens derived from animal manure can survive in a variety of environmental conditions and, consequently cause a variety of illnesses in humans, animals, and other livestock [7]. Although effluent quality standards have long been established, farmers face difficulties in attaining these standards due to the high costs associated with capture and remediation. With increasing environmental concern and awareness of the health risks in connection with the Clean 
Water Act, there is an urgent need to develop cost-effective decentralized pollution prevention technologies to remove pathogenic bacteria from livestock farming effluent. Such technologies will be beneficial for not only livestock production practices, but also the health and safety of the adjacent environment and its residents.

Cost-effective technologies for agricultural wastewater treatment have been intensely applied in practice and debated in academia, both working towards improving discharge quality and community confidence. Many existing animal waste disposal systems are still not accepted as an appropriate treatment due to the remaining elevated health risk derived from pathogens [1,3]. Modifications or combinations of wetland systems designed to treat domestic and dairy farming wastewater have shown high removal rates of organic carbon and nutrients $[8,9]$. Soil filtration has also been long cited as a potential low-cost process to remediate wastewater. Numerous studies have documented that soil filtration systems reduced levels of nitrogen, phosphorus, organic carbon, and microorganisms from wastewater [10-15]. Locally available and naturally sourced materials and waste byproducts have also been found to provide high phosphate removal rates via the adsorption process in filtration systems [12,16]. A variety of designs and operational conditions of soil filters and characteristics of influents have resulted in different removal rates for contaminants [17-19]. It was reported that soil columns effectively removed viruses from treated wastewater with a filter depth of at least $80 \mathrm{~cm}[10,15]$. However, increasing the flow rate led to a reduction of virus removal efficiency in soil filter columns [15]. Multi-soil-layer (MSL) systems were demonstrated to have a moderate to high removal rate of fecal bacteria in domestic wastewater [18,20]. A study of an MSL system packed with Leilehua soil potentially removes a high percentage of phosphate and organic nitrogen from dairy farm effluent to meet the requirements of the Hawaii Department of Health [12]. However, this technology is still not accepted as a means to treat wastewater in the United States because of its inconsistency in producing water that meets either State or National Standards. A particular concern of this treatment method remains the high degree of variability in the removal of bacteria.

The continuous transport of bacteria through soil columns has been seen to increase the bacterial concentration in the associated porous media. Several studies have demonstrated varying transport and adsorption of microorganisms in columns packed with low-cost materials such as sand $[13,21-29]$ and soil $[10,13,15,26,30]$. Bacterial retention in porous media is caused by an adsorption mechanism due to the physical-chemical interaction of bacteria, surface properties and the solid phase [21,24,31,32]. A previous study noted that different soil types did not significantly affect the retention of bacteria, but acidic soils were documented as a better medium for bacterial adsorption than alkaline soils [30]. Additionally, increasing the positive charge surface of filter media was seen to improve bacterial adsorption $[33,34]$. The depositing of motile bacteria provides a more favorable means of collection than that of nonmotile bacteria [26]. This is because, surface collectors are reduced, and adsorption sites are blocked at equilibrium conditions for non-motile bacteria. Consequently, retained bacteria can be washed out of adsorption sites to reduce blockages [30]. This may however cause inefficiency in removing bacteria within column system over operation time.

Biological interactions play a significant role for the regulation of bacterial populations in environmental microbial ecology. Protozoa are known as predators in both soil and water environments and can regulate bacterial populations [35-40] in wastewater treatment systems [41-43]. The addition of E. coli to soil causes an increase in the population of indigenous soil protozoa [35]. In a column experiment where exogenous bacterial cells were added to the column, the proliferation of protozoa was observed. Furthermore, an E. coli reduction in estuarine water has been attributed the presence of protozoa [44]. In bioreactor systems, the reduction of protozoa populations results in an abundance of assimilated bacteria [42]. According to González et al. (1990), protozoa grazing causes the elimination of Enteroccocus faecalis [36]. Previous studies have shown that soil microbes, fecal bacteria, and a pollutant degrader were digested by protozoa [39,40,45-47]. Ciliate 
species were observed as major predators in removing pathogenic parasitic protozoa in aquatic environments [48]. Protozoa predation was considered as the main mechanism for bacterial removal in onsite wastewater treatment systems [23,33,47,49-51]. Retained, immobilized, and biofilm-associated bacteria in biosand filters were eliminated by protozoa $[47,52,53]$. Oxytrichidae and ciliata were found to be grazers in a slow sand filter $[48,52]$. Decamp et al. (1999) reported that the moderate grazing rate of protozoa ranged from 9.5 to 49 bacteria/protozoa/hour for a planted and unplanted bed wetland [41]. An extensive review highlighted that the grazing rates of free-living protozoa were $10^{3}$ to $10^{5}$ bacteria/ciliate/hour and increase with increasing prey density [49]. Another study cited by Schlimme et al. (1999) reported that flagellate and ciliate protozoa have different grazing rates [54]. Protozoa are also found to have different ingestion and digestion rates for different types of bacteria under different environmental conditions [36]. Nevertheless, protozoa have a significant impact in regulating bacterial populations in natural environments.

The combination of both increasing bacterial adsorption by soil media rich in positive charges, and bacterivory by the inclusion of indigenous protozoa in a filtration system, may provide a cost-effective and sustainable approach to removing pathogenic microorganisms from swine wastewater. The Hawaiian Islands are volcanic in origin, and the soil is rich in iron oxides. Nevertheless, little information is available about the removal of bacteria passing through this particular natural medium. This study aims to examine the bacterial removal in Leilehua soil filters and the role of indigenous soil protozoa as an active biological factor for improving efficiency. A laboratory strain of Gram-negative bacteria, $E$. coli ATCC29522, was used as the model organism. A series of filtration experiments were conducted in a laboratory scale filtration system to study the effects of bacterial adsorption and predation in soil filters.

\section{Materials and Methods}

\subsection{Soil Microcosm Experiment}

Soil column experiments were performed in polyvinyl chloride (PVC) pipes (inner diameter: $10.1 \mathrm{~cm}$; length: $38 \mathrm{~cm}$ ) (Figure 1). Leilehua soil was used as a column packing substrate. The properties of Leilehua soil have been described in detail in a previous study [12]. Leilehua soil was freshly collected and dried at room temperature. Then, soil was cracked and sieved to select granules with sizes ranging from 7.0-8.0 mm, which were subsequently dry-packed into the columns by batch pouring to achieve a consistent final media depth of $38 \mathrm{~cm}$. Before starting the experiments, all soil columns were initially water saturated by feeding in a $0.01 \mathrm{M} \mathrm{CaCl}_{2}$ salt solution overnight with a flow rate of $8.0 \mathrm{~L} /$ day. Artificial swine wastewater (N: $750 \mathrm{mg} / \mathrm{L}, \mathrm{P}: 75 \mathrm{mg} / \mathrm{L}, \mathrm{K}: 750 \mathrm{mg} / \mathrm{L}$, Ca: $100 \mathrm{mg} / \mathrm{L}, \mathrm{Mg}: 25 \mathrm{mg} / \mathrm{L}, \mathrm{Na}: 150 \mathrm{mg} / \mathrm{L}$ ) was prepared based on the actual constituents of swine wastewater sampled in Oahu, Hawaiian Islands. The artificial influent was fed into the columns using peristaltic pumps with a high and low input $E$. coli concentration corresponding to loading rates of $10^{10} \mathrm{CFU} / \mathrm{cm}^{2}$. day and $10^{8} \mathrm{CFU} / \mathrm{cm}^{2}$. day, respectively. The flow rate amounted to a volumetric loading of ca. $100 \mathrm{~mL} / \mathrm{cm}^{2}$ per day. This was through an inlet port located at the top of the PVC pipe's manifold. Effluent gradually drained out via gravitational force at the bottom of the soil columns via an outlet tube. Samples were collected at 2-hour intervals initially and then at 4-hour intervals. 


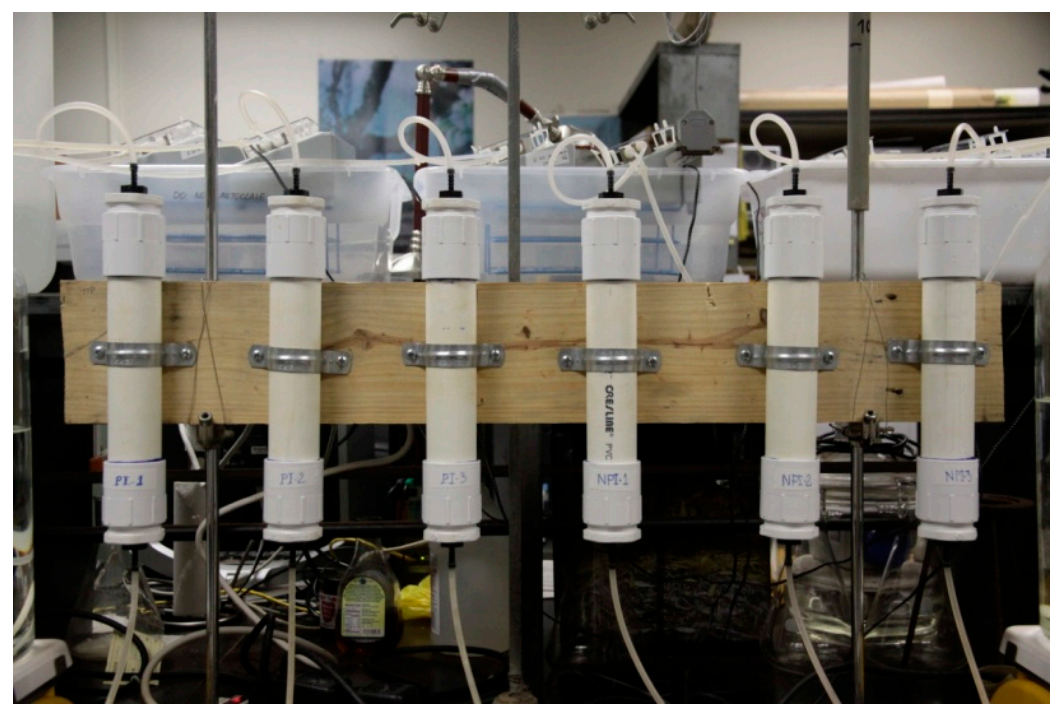

Figure 1. The microcosm MSL systems.

\subsection{Microorganisms and Culture}

The E. coli strain ATCC 29522 was used as the model organism in the experiments. Fresh stationary-phase cells were prepared by inoculating fresh overnight single colonies from TSA agar plates into LB broth, growing at $37^{\circ} \mathrm{C}$ with continuous agitation, and harvesting at the stationary phase (OD600 > 1.2). The collected cells were centrifuged at $10,000 \times g$ for $3.0 \mathrm{~min}$ followed by a washing with phosphate buffered saline (PBS) water for three cycles. The PBS consisted of $8.0 \mathrm{~g} \mathrm{NaCl}, 0.2 \mathrm{~g} \mathrm{KCl}, 0.2 \mathrm{~g} \mathrm{KH}_{2} \mathrm{PO}_{4}$, and $1.15 \mathrm{~g}$ $\mathrm{Na}_{2} \mathrm{HPO}_{4}$. The harvested bacterial cells were suspended in PBW to make a stock solution with an approximate concentration of $10^{8} \mathrm{CFU} / \mathrm{mL}\left(\mathrm{OD}_{600}=0.3\right)$; prepared as the working solution for the experiments. Media containing suspended bacterial cells were kept at $4{ }^{\circ} \mathrm{C}$ to minimize cell growth or decay during experiments. During the experimental period, no marked growth or decay of bacteria within the influent was observed.

\subsection{Protozoa Growth in Soil Columns}

Additionally, using the same soil column setup (Figure 1), a soil column study was carried out to investigate the growth of protozoan populations in response to the supply of E. coli cells as prey within the soil. Six soil columns were divided into two sets; one set was periodically treated with $200 \mathrm{mg} / \mathrm{L}$ of cycloheximide (i.e., cycloheximide-treated) to inhibit protozoa growth and reduce protozoan activities, while the other set was not treated with cycloheximide (i.e., natural protozoa growth (hereinafter NPG). All filter columns were fed with $2.0 \mathrm{~L} /$ day $0.01 \mathrm{M} \mathrm{CaCl}_{2}$ solution containing approximately $10^{5}-10^{6} \mathrm{CFU} / \mathrm{mL}$ of E. coli cells. The average loading rate of targeting bacteria was $1.87 \times 10^{7} \mathrm{CFU} / \mathrm{cm}^{2}$. day. This is significantly higher than the native E. coli population density typically found in Leilehua soil ( $<10 \mathrm{CFU} / \mathrm{g}$ ). The $\mathrm{CaCl}_{2}$ solution with no additional nutrient minimized any unexpected growth of bacteria and protozoa during the transport of bacteria through the soil columns. Effluent was drained continuously through an outlet at the bottom of the columns, and the concentration of E. coli cells was determined at 1-day intervals.

\subsection{Soil Filtration and Protozoa Predation}

The objective of this experiment was to investigate the removal of E. coli in the soil filter column with protozoa predation. The experiment was carried out in replicated soil filter columns with two treatments. One treatment was, soil columns with a pre-enriched protozoa (PEP) population and amended nutrient source $(50 \mathrm{mg} / \mathrm{L}$ of sucrose) in the feeding water solution. The soil columns were continuously fed to stimulate the growth of indigenous soil protozoa. After enrichment, the protozoa population was observed to increase up to levels of $10^{4}-10^{5} \mathrm{MPN} / \mathrm{mL}$ in the effluent solution. The other treatment 
involved soil columns with natural protozoa growth (NPG) in response to the spiked bacterial cells. Soil columns of both treatments were continuously fed with artificial swine wastewater with a concentration of $E$. coli at approximately $10^{5}-10^{6} \mathrm{CFU} / \mathrm{mL}$. Effluents were collected in one-liter plastic bottles at the outlet at 8-hour intervals for the first 7 days and then daily for the remaining time course of the experiment.

The abundance of indigenous soil protozoa and absorbed E. coli in the soil media was also determined at the end of the experiments. All experimental soil filters were interrupted after 20 days, and soil samples were collected at different depths once the effluent had drained from each of the columns. Soil profiles were cut into five equal sections along the depth. All samples were immediately processed to quantify the numbers of active protozoa and trapped bacterial cells in the soil media.

\subsection{Quantification of Microorganisms}

E. coli were quantified based on standard methods: water and soil samples were processed immediately after collection. E. coli in the influent and effluent were enumerated using the membrane filtration method [55]. For water samples, a serial dilution from $10^{-1}$ to $10^{-5}$ was prepared by transferring $1.0 \mathrm{~mL}$ to $9.0 \mathrm{~mL}$ of sterile PBS. For soil samples, wet soil samples (5 g) were suspended in $45 \mathrm{~mL}$ of sterile deionized (DI) water. A subsequent transfer of $1.0 \mathrm{~mL}$ to $9.0 \mathrm{~mL}$ of sterile PBS was undertaken to establish serial dilutions. Ten milliliters of the aliquot dilutions were then filtered through $0.45 \mu \mathrm{m}$ sterile GN-6 membranes (Pall Life Science, Port Washington, NY, USA). The membranes were then placed on modified membrane thermotolerant E. coli (mTEC) agar for selective E. coli enumeration. All culture plates were then incubated in a water bath set at $35^{\circ} \mathrm{C}$ for $2 \mathrm{~h}$, and then overnight at $44.5^{\circ} \mathrm{C}$.

Protozoa enumeration: protozoa in water samples were quantified by using the most probable number (MPN) method [35]. Serial dilutions from $10^{-1}$ to $10^{-4}$ were prepared by transferring $1.0 \mathrm{~mL}$ of the samples to $9.0 \mathrm{~mL}$ of Page's amoeba saline (PAS) buffer. For soil samples, the protozoa population was quantified using the MPN method described in the previous study [56]. Wet soil samples (10 g) were suspended in $90 \mathrm{~mL}$ of sterile DI water in $250 \mathrm{~mL}$ flasks and were agitated for $3 \mathrm{~min}$. A serial dilution was made by subsequently transferring $1.0 \mathrm{~mL}$ of the suspension into $9.0 \mathrm{~mL}$ of PAS buffer to establish a serial dilution from $10^{-2}$ to $10^{-5}$. Then, $20 \mu \mathrm{L}$ of E. coli at a concentration of $10^{8}-10^{9}\left(\mathrm{OD}_{600}=0.4\right)$ was spiked as the only prey source. The ratio of prey and predator for protozoa recovery was approximately 1:5 [35]. The culture plates were incubated in the dark at $10{ }^{\circ} \mathrm{C}$ for $1-3$ weeks and were periodically examined for the presence or absence of protozoa using an inverted microscope.

\section{Results}

\subsection{Sorption of Bacteria by Leilehua Soil}

The sorption of E. coli to soil filtration media was tested at two bacterial loading rates. The high input influent concentrations were $10^{8} \mathrm{CFU} / \mathrm{mL}$, and the lower level was $10^{6} \mathrm{CFU} / \mathrm{mL}$, which corresponded to loading rates of $10^{10} \mathrm{CFU} / \mathrm{cm}^{2} \cdot$ day and $10^{8}$ $\mathrm{CFU} / \mathrm{cm}^{2}$.day, respectively. Figure 2 shows the removal of $E$. coli by MSL mini-columns. The effluent $E$. coli concentration from the high bacterial loading rate gradually increased after $6 \mathrm{~h}$ of feeding, suggesting that the bacterial adsorption was being gradually limited over time. Similarly, the effluent $E$. coli concentration from the low bacterial loading rate also increased over time. However, the columns displayed an initial uptake of bacterial adsorption at the onset, but this capacity to absorb was exceeded once more bacterial cells were loaded. The experimental results indicated that Leilehua soil exhibits adsorption affinity to bacteria. 

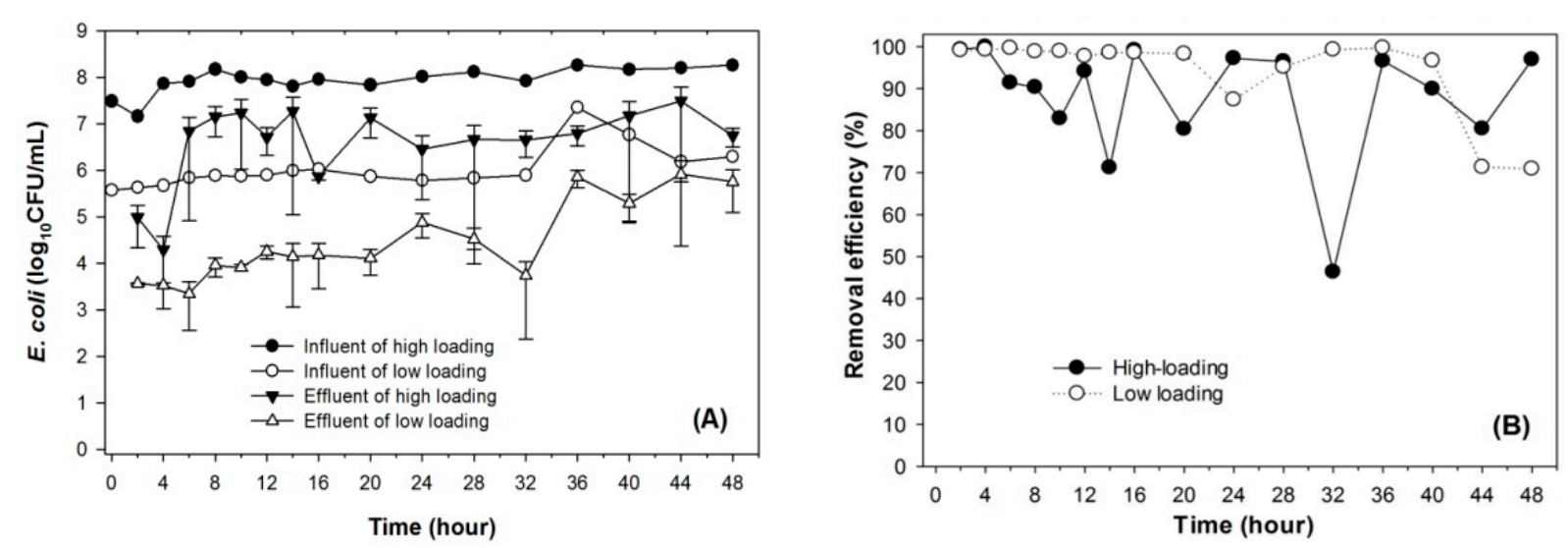

Figure 2. Adsorption of E. coli to the soil columns at two different bacterial loadings. (A) Influent and effluent concentrations, (B) Removal efficiencies.

The soil columns that had lower bacterial loading rates seemed to have a greater extent of E. coli removal than those with high input rates. However, the removal of E. coli was found not to be stable. The average removal efficiencies of both column treatments were $95.52 \%$ and $96.47 \%$ for high and low rates, respectively. This preliminary data suggests that MSL could remove almost all of the extremely high input E. coli concentration $\left(10^{6}-10^{8}\right.$ $\mathrm{CFU} / \mathrm{mL}$ ).

\subsection{Protozoa Response to the Addition of E. coli}

The population dynamics of indigenous soil protozoa by nutrient sources from absorbed E. coli cells was examined in soil microcosm columns. It was seen that protozoa initially grew in the columns when they were fed with a $\mathrm{CaCl}_{2}$ solution containing an E. coli concentration of $10^{5}-10^{6} \mathrm{CFU} / \mathrm{mL}$. Figure $3 \mathrm{~A}$ shows that the indigenous protozoa in Leilehua soil were recovered from the columns, and they were still detected in the column effluents after four days. This result suggested that the native protozoa population increased and likely used the retained E. coli cells as food for growth. Continuously applying E. coli into the columns stimulated the proliferation of protozoa. However, low numbers of protozoa were detected in the column effluent water. A possible explanation is the low movement of protozoa within the soil columns, as the treating water containing the protozoa was passing through pore spaces. Abundant protozoa may reside in soil media where there are plenty of trapped E. coli serving as the food source. In contrast, there was no detection of protozoa in the water outlets of the columns periodically treated with $200 \mathrm{mg} / \mathrm{L}$ cycloheximide. With this level of inhibiting factor, protozoa in soil media did not grow [57]. Thus, the E. coli removal efficiencies in these filter columns were attributed to physicochemical factors.

Protozoan bacterivory in soil media helps to maintain a higher removal rate of E. coli than that seen without protozoa growth. Analogous to the primarily results, efficient $E$. coli removal was achieved in the soil microcosm columns. The spiked E. coli cells were consistently removed from both treatments when $E$. coli cells were loaded at $1.87 \times 10^{7}$ $\mathrm{CFU} / \mathrm{cm}^{2}$.day into the columns. In total, $99.99 \%$ of feeding bacteria were retained in soil filtration media. However, the removal of E. coli dramatically declined in the soil columns in the absence of a predator after seven days (Figure $3 \mathrm{~B}$ ). The reduction of the removal rate might be due to decreasing adsorption sites, while more bacteria were passing through filtration media. In contrast, the soil columns with the natural recovery of protozoa maintained a stable efficiency. The higher E. coli removal rate in untreated cycloheximde columns after the first week of operation could be due to a combination of physicochemical adsorption and predation by protozoa. The captured E. coli in soil media served as the food supply for the indigenous soil protozoa. 

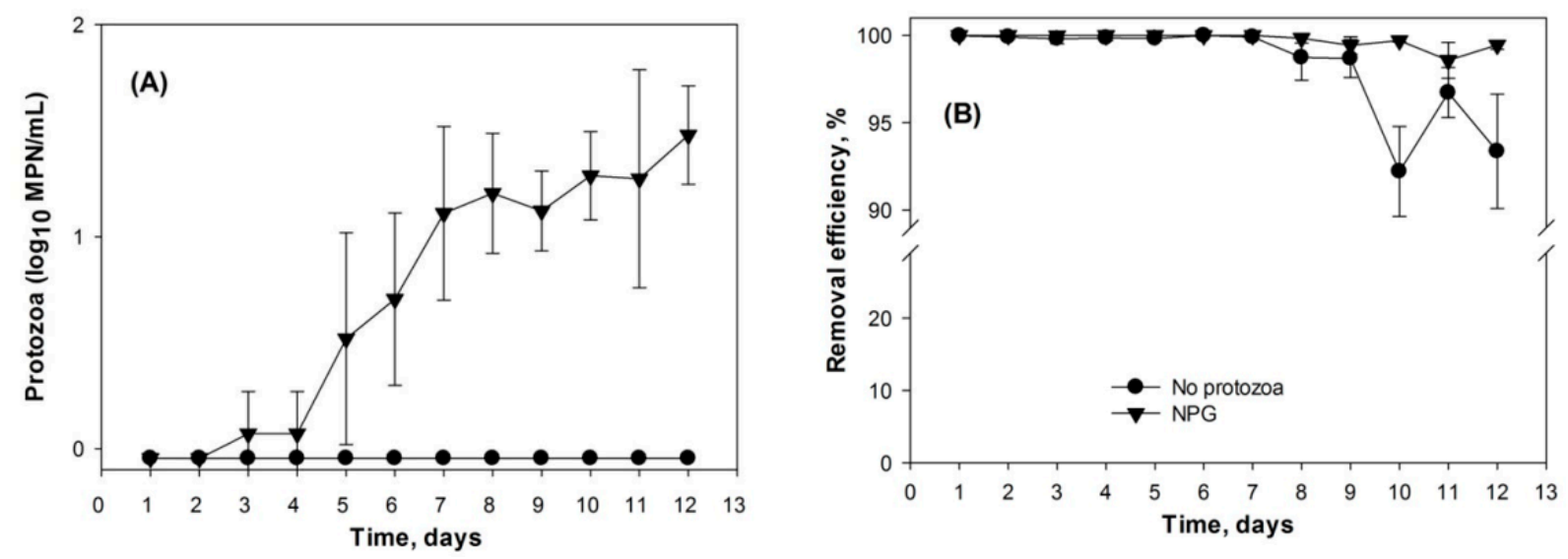

Figure 3. Protozoa response to applying E. coli to soil microcosm column. (A) Protozoa in effluent water, (B) Removal efficiencies.

\subsection{Effects of the Presence of Protozoa on Removal Efficiency of E. coli within Soil Columns}

The third experiment was conducted to compare grazing rates between the PEP and NPG. The protozoa growth in PEP columns was stimulated by external nutrient addition, while protozoa present in NPG columns proliferated on adding E. coli as a food source. The results showed that the numbers of protozoa in treated wastewater increased dramatically after four days (Figure 4A), suggesting that protozoa had naturally recovered when E. coli were initially applied into the soil columns. The results of this experiment aligned with the results of the microcosm experiment. Initially, the protozoa numbers detected in the treated wastewater were very small, yet the concentration increased and reached a stationary level. The protozoa growth in this experiment reached a steady state faster than that in the microcosm experiment (observed by the effluent concentration).
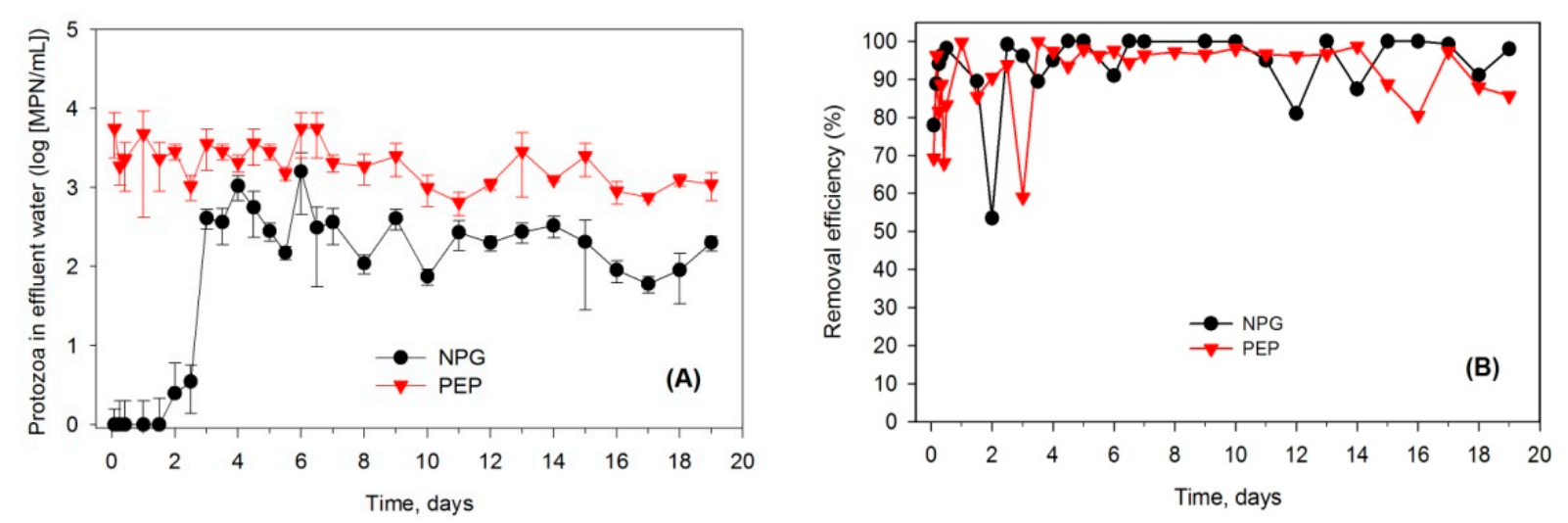

Figure 4. Comparison of the performance between PEP and NPG filters. (A) Protozoa in effluent water, (B) Removal efficiency.

The results showed that a high percentage removal efficiency of $E$. coli was achieved in both PEP and NPG treatment columns (Figure 4B). However, NPG columns were most likely to fluctuate at the commencement of the experiment. This can probably be assumed to occur because the active protozoa failed to recover in time and the capacity of the adsorption sites of soil media might have been exceeded, thus limiting the reduction of the continuously fed bacteria. The soil columns with pre-enriched indigenous protozoa consistently reduced $E$. coli over time. The average removal efficiencies for the entire course of the experiment were observed to be $90.58 \%$ for the PEP treatment and $93.32 \%$ for the NPG treatment. This suggests that protozoa ingested the trapped bacteria within soil media and helped the soil columns maintain a relatively stable E. coli removal rate. Prey-predator mechanisms affecting the changing dynamic of both the bacteria and protozoa populations 
could be a possible explanation. The result of this experiment consistently demonstrated that indigenous protozoan grazing plays an important role in the removal of $E$. coli from wastewater in a soil column system. Overall, there was no significant difference in the E. coli removal efficiency between the pre-enrichment and natural recovery of protozoa. However, the protozoan community stimulated by a nutrient source absorbed E. coli and seemed to be an active predator (Figure $5 \mathrm{~B}$ ). The protozoa concentration was associated with the wastewater solution passing through the soil columns.

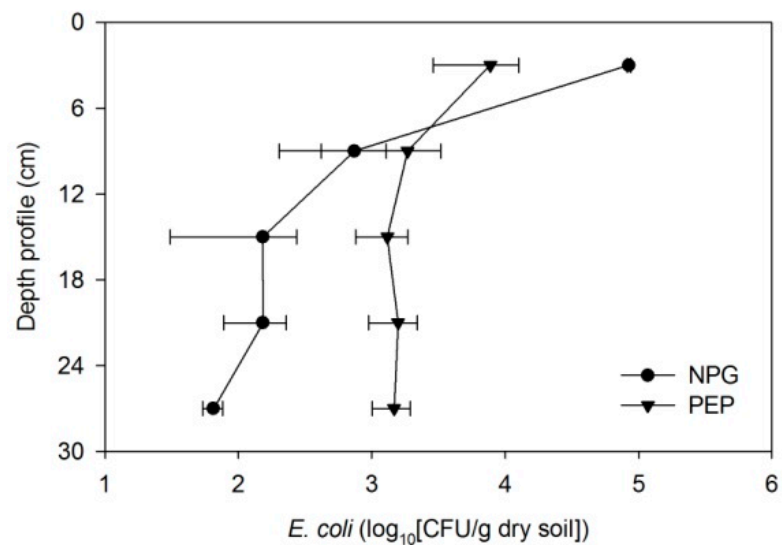

(A)

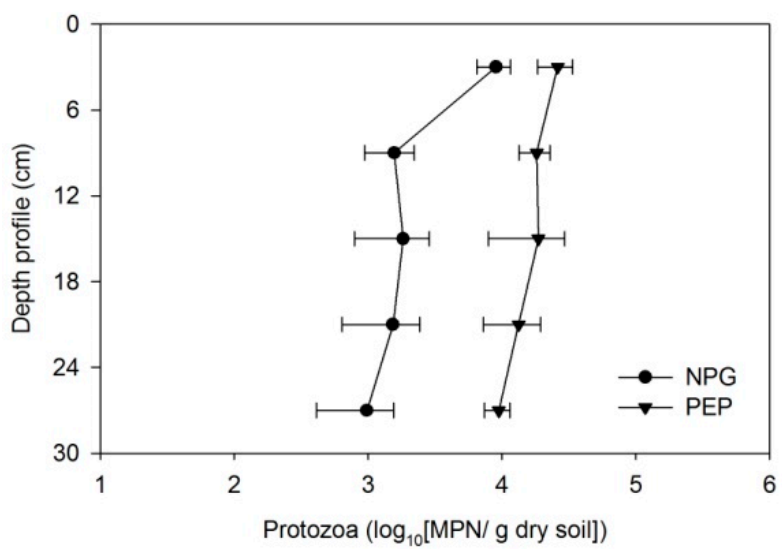

(B)

Figure 5. Distribution of prey and predators in PEP and NPG soil columns concerning filter depth. (A) Absorbed E. coli in the soil media. (B) Protozoa abundance.

\subsection{Enhancement of Bacterial Removal in Two-Stage Filtration}

The MSL swine wastewater treatment was shown to reduce E. coli in the influent. However, the testing columns removed a small fraction of the fecal bacteria, and thus the concentration in the treated water did not meet the official standard level required by the Hawaii Department of Health. Therefore, a system adjustment was made to investigate whether the previous design and operation affected the removal efficiency. Surprisingly, the removal efficiency of E. coli reached 99.99\%, when two MSL columns were placed in sequence and input levels of E. coli were reduced to $10^{4}-10^{6} \mathrm{CFU} / 100 \mathrm{~mL}$. The E. coli concentration in the treated water was less than $10 \mathrm{CFU} / 100 \mathrm{~mL}$, suggesting that the two sequential MSL columns reduced E. coli to ideal target levels (Figure 6).
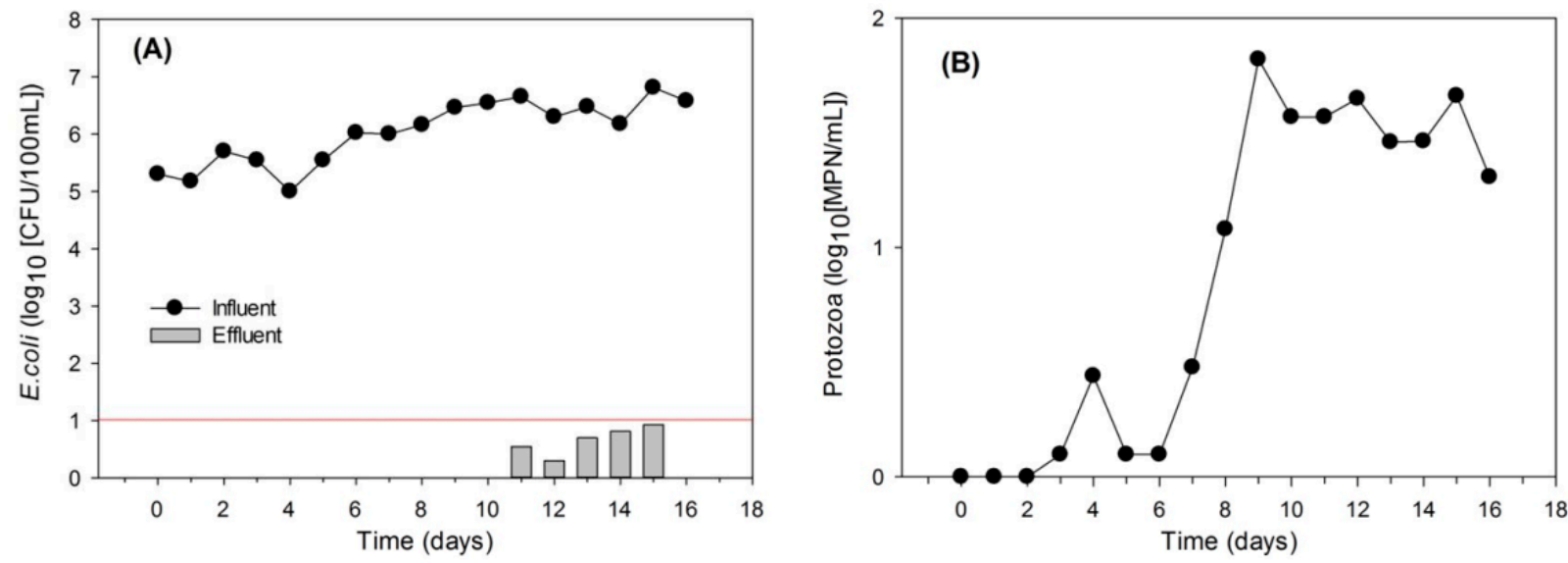

Figure 6. E. coli removal in two sequential columns (A). E. coli in influent and effluent, (B) Protozoa detection in treated wastewater. 


\section{Discussion}

\subsection{Adsorption Capacity of Leilehua to E. coli}

Leilehua soil filters have effectively removed phosphates and inorganic nitrogens in dairy farm effluent wastewater [12]. The high content of ferric oxide in the soil is attributed to increasing bacterial attachment, and this stimulates protozoa grazing of attached bacteria because this soil type has been shown to strongly absorb negatively charged ions $[12,14,16]$. Bacteria cells act in the same manner as organic particles and carry a negative charge. Numerous studies have documented that the metallic oxides that carry a positive charge actively attract and immobilize bacteria in porous media $[33,34,58-60]$. The electrostatic interaction between the two increases the retention of microorganisms in iron-oxide containing filtration media [33,58]. Increasing the fraction of iron coated sand in the filtration system was seen to lead to the enhanced attachment of bacteria to the positivly charged surfaces $[33,61]$. Our results show that Leilehua soil removed E. coli to some extent, but a high variation in the removal efficiency was observed (Figure 2). There might be a finite capacity to retain bacteria in the soil columns. The primary experimental results were in alignment with a previous study in which fecal coliform was reduced in a multi-soil-layer (MSL) system using Leilehua soil [12]. Although the iron-containing filtration medium was shown to improve bacterial retention, it was also found that there was finite adsorption of bacteria to the iron-oxyhydroxide-coated sand [34]. When bacteria fully covers the soil particles, the positive charge on the surfaces may balance the negative charge of the bacteria. Deposits of motile bacteria tend to increase the overall retention of bacteria while nonmotile bacteria tend to block adsorption sites [26]. However, excessive colonization of the bacteria on pore surfaces leads to bioclogging [62]. We assumed that the Leilehua soil has a finite capacity to retain bacteria. Thus, only a small fraction of bacterial adsorption could be achieved in the tested soil columns when they were continuously fed swine wastewater.

\subsection{Indigenous Soil Protozoa and Bacterial Regulation by Protozoa}

The addition of E. coli to the soil can result in a corresponding increase of the native soil protozoa population [35]. In addition, the discharge of wastewater containing fecal bacteria into adjacent streams can also lead to a response of free-living protozoa that then determine the bacterial levels in aquatic systems $[63,64]$. Our experimental data shows that indigenous protozoa grew in Leilehua soil filters after three days (Figures $3 \mathrm{~A}$ and $4 \mathrm{~A}$ ) following continous feeding with artificial swine wastewater. The numbers of protozoa detected in the treated effluent at a steady state were $10^{2}-10^{3} \mathrm{MPN} / \mathrm{mL}$. However, the protozoa population that colonized soil filtration media was higher than that in the effluent water. A previous study reported that the protozoa number increased approximately 150-fold after three days of incubation in soil microcosms containing E. coli [35]. Although protozoa are beneficial in grazing the bacteria retained in MSL systems, it is noted that pathogenic protozoa might be present in the water outlets of such treatment systems. However, previous research has reported the predation of pathogenic species including Giardia spp. cyst and Cryptosporidium paroum oocyst by ciliate protozoa [48]. Therefore, it is noteworthy that higher numbers of protozoa resided in the top media portion of the columns, which suggests absorbed E. coli might be attributable to protozoa multiplication and colonization. The protozoa abundance in soil media was highly positively correlated with the absorbed E. coli along the filtration column depth (Figure 7A). This predator-prey relationship demonstrates that the presence of bacterivores may impact the flux of bacteria in swine effluent wastewater applied to a pooled community of protozoa. However, this study did not provide any direct evidence to support this assumption. The sole clue for the role of protozoa in regulating the bacteria in soil columns was the removal efficiency. For the pre-enrichment soil columns, there was an unlikely positive correlation between the pre-enriched protozoa population and concentration of absorbed E. coli cells. A possible explanation for this is due to the existing alternative nutrients for protozoa remaining from the enrichment process. Together, the results suggest that the bacterial feeding protista were 
actively responding to the absorbed prey, while the pre-enrichment community, via the organic substrate, was unlikely to actively graze the bacteria for energy. As a consequence, the established protozoa community grazes on the retained bacteria and eliminates them from wastewater, leading to an improvement of the treated water.
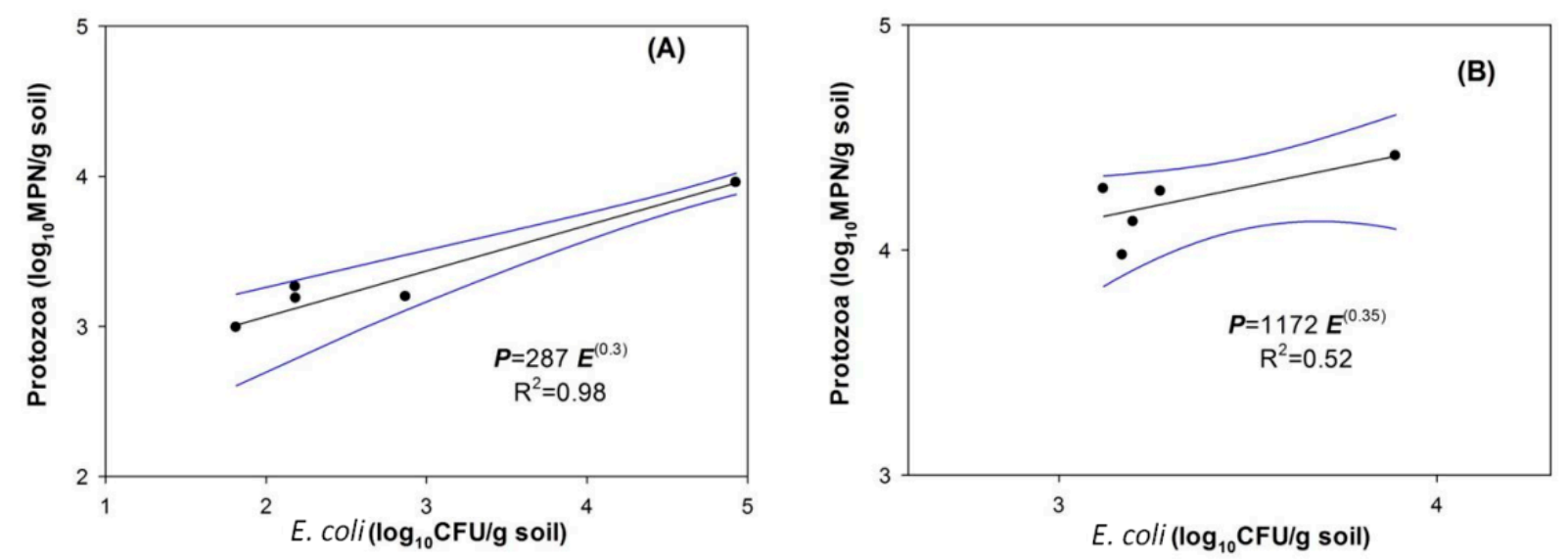

Figure 7. The correlation between protozoa abundance and attached E. coli along the filter depth. (A) NPG columns, (B) PEP columns.

\subsection{Effects of Protozoa on E. coli Removal Efficiencies in the Soil Columns}

Grazing mechanisms result in a microbial population shift of predators and preys in soil and aquatic systems [37,39]. Protozoan grazing also affects the interactions between bacteria and other microorganisms in the soil [35,39]. Numerous studies have documented that predation mechanisms play a significant role in reducing the bacteria in water and wastewater filtration systems $[23,33,47,49-52]$. This study showed that the presence of bacterivorous protozoa in the soil columns stimulated a more stable removal efficiency of fecal bacteria, than that in the absence of protozoa predation (Figure 3B). The clearance rate of protozoa to fecal bacteria obtained from the classical model fitting was $20 \mu \mathrm{L}$ per predator per hour [63]. A report cited by Schlimme et al. (1997), showed protozoa consumption rates of 9-266 bacteria per hour for a flagellate and 200-5000 per hour for a ciliate [54]. Bacterivorous protozoa were documented to have different feeding rates, depending on their species and prey density $[49,54,65]$. Although predation by protozoa was revealed as the mechanism of bacterial destruction $[46,47,52]$, there is little information available to support the percentage of bacteria removal by protists in a filtration system. A previous study showed that ciliates ingested attached bacteria at the rate of $1382 \pm 1029$ cells predator ${ }^{-1} \mathrm{~h}^{-1}$, but the grazing rate reduced by approximately one quarter in an infiltration system [66]. The mass balance calculation, with the assumption of unremarkable cell death during the experiments, showed that the protozoa grazing rates in the replicate Leilehua soil filters were 146.2 cells protozoa ${ }^{-1} \mathrm{~h}^{-1}$ for the NPG columns and 46.2 cells protozoa ${ }^{-1} \mathrm{~h}^{-1}$ for the PEP columns (Table 1 ). These grazing rates are much lower than the values reported by Eisenmann et at (1998) [66], but higher those reported for wetland systems [41]. There was higher grazing in the NPG than in the PEP filters, again inferring that there were more active predators in the NPG filters than in the PEP filters. The removal efficiencies between these two treatments were not significantly different. However, a previous study reported that the destruction of bacteria increased with increasing concentrations of protozoa in the bioretention column [33]. Although the PEP might be less active, the higher protozoa population could eliminate E. coli in amounts similar to the NPG. 
Table 1. Mass balance of the E. coli and protozoa grazing rate in the MSL mini-columns.

\begin{tabular}{|c|c|c|c|c|c|c|c|c|}
\hline \multirow{2}{*}{\multicolumn{2}{|c|}{ Treatment }} & \multicolumn{2}{|c|}{$\begin{array}{l}\text { Total Mass E. coli in Water, } \\
\text { CFU }\end{array}$} & \multicolumn{3}{|c|}{ Total Mass Absorbed E. coli in Soil, CFU } & \multirow{2}{*}{$\begin{array}{c}\text { Active } \\
\text { Predators in } \\
\text { Soil } \\
\text { Column, MPN }\end{array}$} & \multirow{2}{*}{$\begin{array}{c}\text { Grazing Rate } \\
\text { (E. coli/Protozoa.h) }\end{array}$} \\
\hline & & Influent & Effluent & $\begin{array}{l}\text { Retained } \\
\text { Cells }\end{array}$ & Live Cells & Death Cells & & \\
\hline \multirow{2}{*}{ NPG } & Column 1 & $7.44 \times 10^{9}$ & $1.10 \times 10^{9}$ & $6.35 \times 10^{9}$ & $5.98 \times 10^{7}$ & $6.29 \times 10^{9}$ & $1.00 \times 10^{7}$ & 146.0 \\
\hline & Column 2 & $1.06 \times 10^{10}$ & $3.15 \times 10^{9}$ & $7.45 \times 10^{9}$ & $5.82 \times 10^{7}$ & $7.40 \times 10^{9}$ & $1.17 \times 10^{7}$ & 146.5 \\
\hline \multirow{2}{*}{ PEP } & Column 1 & $8.36 \times 10^{9}$ & $5.24 \times 10^{8}$ & $7.84 \times 10^{9}$ & $1.50 \times 10^{7}$ & $7.82 \times 10^{9}$ & $5.37 \times 10^{7}$ & 33.9 \\
\hline & Column 2 & $9.38 \times 10^{9}$ & $4.23 \times 10^{8}$ & $8.96 \times 10^{9}$ & $6.30 \times 10^{6}$ & $8.95 \times 10^{9}$ & $6.74 \times 10^{7}$ & 30.9 \\
\hline
\end{tabular}

\subsection{Sequential Design Filters for Better Removal}

Although the MSL mini-column with protozoa growth was seen to reduce bacteria, the tested effluent bacteria concentration was still higher than the standard for recycled water quality. It is widely reported that soil filtration often removes bacteria and viruses to $2-3 \log$ unit levels $[11,53,67]$. The previous study that addressed the removal rates of coliforms and pathogens showed that they were increased from a moderate level for the one-stage MSL to a higher level for the two-stage MSL system $[18,20]$. This finding is consistent with previous studies by Latrach et al. (2015) and Latrach et al. (2018), who studied different configurations of MSL for the removal of coliform and human pathogens. Despite the complex sorption mechanism that possibly occurred when a multiconstituent aqueous solution like swine effluent was applied to the soil columns, the absorbed E. coli has a nonlinear relationship with respect to the filter depth (Figure 5A).

Previous studies have reported that the concentrations of fecal bacteria and pathogens in swine effluent were at least $10^{5} \mathrm{CFU} / 100 \mathrm{~mL}[6,68]$. In this study, the bacterial concentration ranged from $10^{6}-10^{7} \mathrm{CFU} / 100 \mathrm{~mL}$ in the influent. The E. coli concentration dramatically increased in the effluent in the single column system. A previous study showed that a metallic oxide-coated sand filter, incorporated with bacterivory predation, was efficient in removing pathogenic bacteria [33]. Leilehua soil with iron oxide content has an adsorption affinity to bacteria. However, continuous loading might have exceeded the finite loading capacity of the filter columns. In addition, a short hydraulic retention time $(\mathrm{HRT}=4 \mathrm{~h})$ may also reduce protozoa grazing rates due to a decreased contact time. It seems that the finite adsorption and predation in this particular study design may have limited the effective removal of E. coli. By placing two columns in sequence, this limitaton was overcome. Thus, a high removal rate was obtained in the two sequential MSL mini-columns.

\section{Conclusions}

The MSL mini-columns packed with iron oxide rich soil were shown as a potential treatment means to remove bacteria in artificial swine wastewater. The experimental results suggest that Leilehua soil also contains native predators that are active in grazing the loaded microbial contaminants. At least $95.52 \%$ of the E. coli were absorbed by soil media and were then removed by protozoa bacterivory. The grazing rates were 146.2 cell protozoa ${ }^{-1} \mathrm{~h}^{-1}$ and 32.4 cell protozoa ${ }^{-1} \mathrm{~h}^{-1}$. The performance of the MSL mini-columns was improved after modification into a serial system. The average removal efficiency in the soil filter with a $30 \mathrm{~cm}$ thickness during a 2-week operation was $99.99 \%$ under a short hydraulic retention time. The bacterial concentrations in the treated water in the two sequential columns meet the R1 standard level for recycled water in Hawaii. This study provides evidence that local natural media can be potentially applicable to use in filter systems for the treatment of agricultural wastewater. However, actual swine wastewater that contains high organic solute and colloid levels should be tested in the same manner, because the experiment conducted in this study used free organic artificial swine wastewater, and it may not be appropriate in practice. 
Author Contributions: Conceptualization, R.Y. and T.Y.; methodology, L.K. and G.P.; software, R.Y.; validation, L.K. and T.Y.; formal analysis, L.K. and T.Y.; investigation, L.K., T.Y.; and R.Y.; resources, T.Y. and R.Y.; data curation, L.K., T.Y. and R.Y.; writing—original draft preparation, L.K.; writingreview and editing, L.K. and T.Y.; visualization, L.K., T.Y. and R.Y.; supervision, T.Y. and R.Y.; project administration, T.Y. and R.Y.; funding acquisition, L.K., T.Y., R.Y. and G.P. All authors have read and agreed to the published version of the manuscript.

Funding: This research received no external funding.

Institutional Review Board Statement: Not applicable.

Informed Consent Statement: Not applicable.

Acknowledgments: The authors would like to acknowledge Nigel K. Downes for the language check.

Conflicts of Interest: The authors declare no conflict of interest.

\section{References}

1. Choi, E. Piggery Waste Management; IWA Publishing: London, UK, 2007; Volume 6.

2. Owusu-Twum, M.Y.; Sharara, M.A. Sludge management in anaerobic swine lagoons: A review. J. Environ. Manag. 2020, 271, 110949. [CrossRef]

3. McLaughlin, M.R.; Brooks, J.P.; Adeli, A. Temporal flux and spatial dynamics of nutrients, fecal indicators, and zoonotic pathogens in anaerobic swine manure lagoon water. Water Res. 2012, 46, 4949-4960. [CrossRef]

4. Chee-Sanford, J.C.; Aminov, R.I.; Krapac, I.J.; Garrigues-Jeanjean, N.; Mackie, R.I. Occurrence and Diversity of Tetracycline Resistance Genes in Lagoons and Groundwater Underlying Two Swine Production Facilities. Appl. Environ. Microbiol. 2001, 67, 1494-1502. [CrossRef]

5. Deng, S.; Yan, X.; Zhu, Q.; Liao, C. The utilization of reclaimed water: Possible risks arising from waterborne contaminants. Environ. Pollut. 2019, 254, 113020. [CrossRef] [PubMed]

6. Brooks, J.P.; Adeli, A.; McLaughlin, M.R. Microbial ecology, bacterial pathogens, and antibiotic resistant genes in swine manure wastewater as influenced by three swine management systems. Water Res. 2014, 57, 96-103. [CrossRef] [PubMed]

7. Guan, T.Y.; Holley, R.A. Pathogen survival in swine manure environments and transmission of human enteric illness-a review. J. Environ. Qual. 2003, 32, 383-392. [CrossRef] [PubMed]

8. Vymazal, J. Removal of nutrients in various types of constructed wetlands. Sci. Total Environ. 2007, 380, 48-65. [CrossRef]

9. Zhang, L.; Zhang, L.; Liu, Y.; Shen, Y.; Liu, H.; Xiong, Y. Effect of limited artificial aeration on constructed wetland treatment of domestic wastewater. Desalination 2010, 250, 915-920. [CrossRef]

10. Gerba, C.P.; Lance, J.C. Poliovirus removal from primary and secondary sewage effluent by soil filtration. Appl. Environ. Microbiol. 1978, 36, 247-251. [CrossRef]

11. Gilbert, R.G.; Gerba, C.P.; Rice, R.C.; Bouwer, H.; Wallis, C.; Melnick, J.L. Virus and bacteria removal from wastewater by land treatment. Appl. Environ. Microbiol. 1976, 32, 333-338. [CrossRef]

12. Pattnaik, R.; Yost, R.S.; Porter, G.; Masunaga, T.; Attanandana, T. Improving multi-soil-layer (MSL) system remediation of dairy effluent. Ecol. Eng. 2008, 32, 1-10. [CrossRef]

13. Powelson, D.K.; Simpson, J.R.; Gerba, C.P. Effects of organic matter on virus transport in unsaturated flow. Appl. Environ. Microbiol. 1991, 57, 2192-2196. [CrossRef] [PubMed]

14. Wakatsuki, T.; Esumi, H.; Omura, S. High performance and nitrogen and phosphorus-removable on-site domestic waste water treatment system by multi-soil-layering method. Water Sci. Technol. 1993, 27, 31-40. [CrossRef]

15. Wang, D.S.; Gerba, C.P.; Lance, J.C. Effect of soil permeability on virus removal through soil columns. Appl. Environ. Microbiol. 1981, 42, 83-88. [CrossRef] [PubMed]

16. Boyer, T.H.; Persaud, A.; Banerjee, P.; Palomino, P. Comparison of low-cost and engineered materials for phosphorus removal from organic-rich surface water. Water Res. 2011, 45, 4803-4814. [CrossRef]

17. Latrach, L.; Ouazzani, N.; Masunaga, T.; Hejjaj, A.; Bouhoum, K.; Mahi, M.; Mandi, L. Domestic wastewater disinfection by combined treatment using multi-soil-layering system and sand filters (MSL-SF): A laboratory pilot study. Ecol. Eng. 2016, 91, 294-301. [CrossRef]

18. Latrach, L.; Ouazzani, N.; Hejjaj, A.; Mahi, M.; Masunaga, T.; Mandi, L. Two-stage vertical flow Multi-Soil-Layering (MSL) technology for efficient removal of coliforms and human pathogens from domestic wastewater in rural areas under arid climate. Int. J. Hyg. Environ. Health 2018, 221, 64-80. [CrossRef] [PubMed]

19. Latrach, L.; Ouazzani, N.; Hejjaj, A.; Zouhir, F.; Mahi, M.; Masunaga, T.; Mandi, L. Optimization of hydraulic efficiency and wastewater treatment performances using a new design of vertical flow Multi-Soil-Layering (MSL) technology. Ecol. Eng. 2018, 117, 140-152. [CrossRef]

20. Latrach, L.; Masunaga, T.; Ouazzani, N.; Hejjaj, A.; Mahi, M.; Mandi, L. Removal of bacterial indicators and pathogens from domestic wastewater by the multi-soil-layering (MSL) system. Soil Sci. Plant Nutr. 2015, 61, 337-346. [CrossRef] 
21. Camper, A.K.; Hayes, J.T.; Sturman, P.J.; Jones, W.L.; Cunningham, A.B. Effects of Motility and Adsorption Rate Coefficient on Transport of Bacteria through Saturated Porous Media. Appl. Environ. Microbiol. 1993, 59, 3455-3462. [CrossRef] [PubMed]

22. Fontes, D.E.; Mills, A.L.; Hornberger, G.M.; Herman, J.S. Physical and chemical factors influencing transport of microorganisms through porous media. Appl. Environ. Microbiol. 1991, 57, 2473-2481. [CrossRef]

23. Weber-Shirk, M.L.; Dick, R.I. Biological mechanisms in slow sand filters. J. Am. Water Works Assoc. 1997, 89, 72-83. [CrossRef]

24. Hendry, M.J.; Lawrence, J.R.; Maloszewski, P. The role of sorption in the transport of Klebsiella oxytoca through saturated silica sand. Ground Water 1997, 35, 574-584. [CrossRef]

25. Stumpp, C.; Lawrence, J.R.; Hendry, M.J.; Maloszewski, P. Transport and Bacterial Interactions of Three Bacterial Strains in Saturated Column Experiments. Environ. Sci. Technol. 2011, 45, 2116-2123. [CrossRef] [PubMed]

26. Camesano, T.A.; Logan, B.E. Influence of Fluid Velocity and Cell Concentration on the Transport of Motile and Nonmotile Bacteria in Porous Media. Environ. Sci. Technol. 1998, 32, 1699-1708. [CrossRef]

27. Bolster, C.H.; Cook, K.L.; Marcus, I.M.; Haznedaroglu, B.Z.; Walker, S.L. Correlating transport behavior with cell properties for eight porcine Escherichia coli isolates. Environ. Sci. Technol. 2010, 44, 5008-5014. [CrossRef]

28. Chen, G.; Walker, S.L. Fecal Indicator Bacteria Transport and Deposition in Saturated and Unsaturated Porous Media. Environ. Sci. Technol. 2012, 46, 8782-8790. [CrossRef]

29. Wang, L.; Xu, S.; Li, J. Effects of Phosphate on the Transport of Escherichia coli O157:H7 in Saturated Quartz Sand. Environ. Sci. Technol. 2011, 45, 9566-9573. [CrossRef] [PubMed]

30. Dhand, N.K.; Toribio, J.-A.L.M.L.; Whittington, R.J. Adsorption of Mycobacterium avium subsp. paratuberculosis to Soil Particles. Appl. Environ. Microbiol. 2009, 75, 5581-5585. [CrossRef] [PubMed]

31. Powelson, D.K.; Mills, A.L. Bacterial enrichment at the gas-water interface of a laboratory apparatus. Appl. Environ. Microbiol. 1996, 62, 2593-2597. [CrossRef]

32. Stevik, T.; Aa, K.; Ausland, G.; Hanssen, J. Retention and Removal of Pathogenic Bacteria in Wastewater Percolating through Porous Media: A Review. Water Res. 2004, 38, 1355-1367. [CrossRef]

33. Zhang, L.; Seagren, E.A.; Davis, A.P.; Karns, J.S. The Capture and Destruction of Escherichia coli from Simulated Urban Runoff Using Conventional Bioretention Media and Iron Oxide-coated Sand. Water Environ. Res. 2010, 82, 701-714. [CrossRef]

34. Mills, A.L.; Herman, J.S.; Hornberger, G.M.; DeJesús, T.H. Effect of Solution Ionic Strength and Iron Coatings on Mineral Grains on the Sorption of Bacterial Cells to Quartz Sand. Appl. Environ. Microbiol. 1994, 60, 3300-3306. [CrossRef]

35. Casida, L.E. Protozoan Response to the Addition of Bacterial Predators and Other Bacteria to Soil. Appl. Environ. Microbiol. 1989, 55, 1857-1859. [CrossRef] [PubMed]

36. González, J.M.; Iriberri, J.; Egea, L.; Barcina, I. Differential Rates of Digestion of Bacteria by Freshwater and Marine Phagotrophic Protozoa. Appl. Environ. Microbiol. 1990, 56, 1851-1857. [CrossRef]

37. Hahn, M.W.; Hofle, M.G. Grazing of protozoa and its effect on populations of aquatic bacteria. FEMS Microbiol. Ecol. 2001, 35, 113-121. [CrossRef]

38. Murase, J.; Noll, M.; Frenzel, P. Impact of Protists on the Activity and Structure of the Bacterial Community in a Rice Field Soil. Appl. Environ. Microbiol. 2006, 72, 5436-5444. [CrossRef]

39. Rønn, R.; McCaig, A.E.; Griffiths, B.S.; Prosser, J.I. Impact of Protozoan Grazing on Bacterial Community Structure in Soil Microcosms. Appl. Environ. Microbiol. 2002, 68, 6094-6105. [CrossRef] [PubMed]

40. Wright, D.A.; Killham, K.; Glover, L.A.; Prosser, J.I. Role of Pore Size Location in Determining Bacterial Activity during Predation by Protozoa in Soil. Appl. Environ. Microbiol. 1995, 61, 3537-3543. [CrossRef] [PubMed]

41. Decamp, O.; Warren, A.; Sanchez, R. The role of ciliated protozoa in subsurface flow wetlands and their potential as bioindicators. Water Sci. Technol. 1999, 40, 91-98. [CrossRef]

42. Pinto, A.J.; Love, N.G. Bioreactor Function under Perturbation Scenarios Is Affected by Interactions between Bacteria and Protozoa. Environ. Sci. Technol. 2012, 46, 7558-7566. [CrossRef] [PubMed]

43. Ravva, S.V.; Sarreal, C.Z.; Mandrell, R.E. Identification of protozoa in dairy lagoon wastewater that consume Escherichia coli O157:H7 preferentially. PLoS ONE 2010, 5, e15671. [CrossRef]

44. Enzinger, R.M.; Cooper, R.C. Role of bacteria and protozoa in the removal of Escherichia coli from estuarine waters. Appl. Environ. Microbiol. 1976, 31, 758-763. [CrossRef]

45. Holmes, D.E.; Nevin, K.P.; Snoeyenbos-West, O.L.; Woodard, T.L.; Strickland, J.N.; Lovley, D.R. Protozoan grazing reduces the current output of microbial fuel cells. Bioresour. Technol. 2015, 193, 8-14. [CrossRef] [PubMed]

46. Ellegaard-Jensen, L.; Albers, C.N.; Aamand, J. Protozoa graze on the 2,6-dichlorobenzamide (BAM)-degrading bacterium Aminobacter sp. MSH1 introduced into waterworks sand filters. Appl. Microbiol. Biotechnol. 2016, 100, 8965-8973. [CrossRef] [PubMed]

47. Haig, S.J.; Schirmer, M.; D'Amore, R.; Gibbs, J.; Davies, R.L.; Collins, G.; Quince, C. Stable-isotope probing and metagenomics reveal predation by protozoa drives E. coli removal in slow sand filters. ISME J. 2015, 9, 797-808. [CrossRef]

48. Siqueira-Castro, I.C.V.; Greinert-Goulart, J.A.; Bonatti, T.R.; Yamashiro, S.; Franco, R.M.B. First report of predation of Giardia sp. cysts by ciliated protozoa and confirmation of predation of Cryptosporidium spp. oocysts by ciliate species. Environ. Sci. Pollut. Res. Int. 2016, 23, 11357-11362. [CrossRef]

49. Wang, M.; Zhu, J.; Mao, X. Removal of Pathogens in Onsite Wastewater Treatment Systems: A Review of Design Considerations and Influencing Factors. Water 2021, 13, 1190. [CrossRef] 
50. Bomo, A.-M.; Husby, A.; Stevik, T.K.; Hanssen, J.F. Removal of fish pathogenic bacteria in biological sand filters. Water Res. 2003, 37, 2618-2626. [CrossRef]

51. Bomo, A.-M.; Stevik, T.K.; Hovi, I.; Hanssen, J.F. Bacterial Removal and Protozoan Grazing in Biological Sand Filters. J. Environ. Qual. 2004, 33, 1041-1047. [CrossRef]

52. Pfannes, K.R.; Langenbach, K.M.W.; Pilloni, G.; Stührmann, T.; Euringer, K.; Lueders, T.; Neu, T.R.; Müller, J.A.; Kästner, M.; Meckenstock, R.U. Selective elimination of bacterial faecal indicators in the Schmutzdecke of slow sand filtration columns. Appl. Microbiol. Biotechnol. 2015, 99, 10323-10332. [CrossRef] [PubMed]

53. Kadam, A.M.; Nemade, P.D.; Oza, G.H.; Shankar, H.S. Treatment of municipal wastewater using laterite-based constructed soil filter. Ecol. Eng. 2009, 35, 1051-1061. [CrossRef]

54. Schlimme, W.; Marchiani, M.; Hanselmann, K.; Jenni, B. Gene transfer between bacteria within digestive vacuoles of protozoa. FEMS Microbiol. Ecol. 1997, 23, 239-247. [CrossRef]

55. USEPA. Method 1603: Escherichia coli (E. coli) in Water by Membrane Filtration Using Modified Membrane-Thermotolerant Escherichia coli Agar (Modified mTEC); Office of Water: Washington, DC, USA, 2002.

56. Stevik, T.K.; Hanssen, J.F.; Jenssen, P.D. A comparison between DAPI direct count (DDC) and most probable number (MPN) to quantify protozoa in infiltration systems. J. Microbiol. Methods 1998, 33, 13-21. [CrossRef]

57. Feng, F.; Goto, D.; Yan, T. Effects of autochthonous microbial community on the die-off of fecal indicators in tropical beach sand. FEMS Microbiol. Ecol. 2010, 74, 214-225. [CrossRef]

58. Bradley, I.; Straub, A.; Maraccini, P.; Markazi, S.; Nguyen, T.H. Iron oxide amended biosand filters for virus removal. Water Res. 2011, 45, 4501-4510. [CrossRef]

59. Lukasik, J.; Cheng, Y.-F.; Lu, F.; Tamplin, M.; Farrah, S.R. Removal of microorganisms from water by columns containing sand coated with ferric and aluminum hydroxides. Water Res. 1999, 33, 769-777. [CrossRef]

60. Gülay, A.; Tatari, K.; Musovic, S.; Mateiu, R.V.; Albrechtsen, H.-J.; Smets, B.F. Internal Porosity of Mineral Coating Supports Microbial Activity in Rapid Sand Filters for Groundwater Treatment. Appl. Environ. Microbiol. 2014, 80, 7010-7020. [CrossRef]

61. Kim, S.-B.; Park, S.-J.; Lee, C.-G.; Kim, H.-C. Transport and retention of Escherichia coli in a mixture of quartz, Al-coated and Fe-coated sands. Hydrol. Process. 2008, 22, 3856-3863. [CrossRef]

62. Cunningham, A.B.; Characklis, W.G.; Abedeen, F.; Crawford, D. Influence of biofilm accumulation on porous media hydrodynamics. Environ. Sci. Technol. 1991, 25, 1305-1311. [CrossRef]

63. Surbeck, C.Q.; Jiang, S.C.; Grant, S.B. Ecological Control of Fecal Indicator Bacteria in an Urban Stream. Environ. Sci. Technol. 2010, 44, 631-637. [CrossRef] [PubMed]

64. Barcina, I.; Lebaron, P.; Vives-Rego, J. Survival of allochthonous bacteria in aquatic systems: A biological approach. FEMS Microbiol. Ecol. 1997, 23, 1-9. [CrossRef]

65. Posch, T.; Pitsch, G.; Bruni, E.P. Protists: Ciliates. In Reference Module in Earth Systems and Environmental Sciences; Elsevier: Amsterdam, The Netherlands, 2021.

66. Eisenmann, H.; Harms, H.; Meckenstock, R.; Meyer, E.I.; Zehnder, A.J.B. Grazing of a Tetrahymena sp. on Adhered Bacteria in Percolated Columns Monitored by In Situ Hybridization with Fluorescent Oligonucleotide Probes. Appl. Environ. Microbiol. 1998, 64, 1264-1269. [CrossRef]

67. Kadam, A.M.; Oza, G.H.; Nemade, P.D.; Shankar, H.S. Pathogen removal from municipal wastewater in Constructed Soil Filter. Ecol. Eng. 2008, 33, 37-44. [CrossRef]

68. Vanotti, M.B.; Szogi, A.A.; Hunt, P.G.; Millner, P.D.; Humenik, F.J. Development of environmentally superior treatment system to replace anaerobic swine lagoons in the USA. Bioresour. Technol. 2007, 98, 3184-3194. [CrossRef] [PubMed] 